\title{
NURSING CARE PROCEDURES IN RESPONSE TO ADVERSE EVENTS TO BLOOD DONATION $^{1}$
}

\author{
Karla Fabiana Nunes da Silva², Elizabeth Barichello ${ }^{3}$, Ana Lúcia de Mattia ${ }^{4}$, Maria Helena Barbosa ${ }^{5}$
}

\footnotetext{
${ }^{1}$ Extract from the dissertation - Analysis of adverse events with blood donation ans nursing procedures adopted, submitted to the Graduate Program in Health Care of Universidade Federal do Triângulo Mineiro (UFMT), in 2012.

${ }^{2}$ M.Sc. in Health Care. R.N. at Hemocentro Regional de Uberaba, Fundação Hemominas. Uberaba, Minas Gerais, Brazil. Email: enf_karla@yahoo.com.br

${ }^{3}$ Ph.D. in Nursing. Adjunct Professor at the Nursing Undergraduate Program and the Graduate Program in Health Care at UFTM. Uberaba, Minas Gerais, Brazil. Email: lizabarichello@yahoo.com.br

${ }^{4}$ Ph.D. in Nursing. Adjunct Professor at the Nursing Undergraduate Program of the Universidade Federal de Minas Gerais. Belo Horizonte, Minas Gerais, Brazil. Email: almattia@uol.com.br

${ }^{5}$ Ph.D. in Nursing. Adjunct Professor at the Nursing Undergraduate Program and the Graduate Program in Health Care at UFTM. Uberaba, Minas Gerais, Brazil. Email: mhelena331@hotmail.com
}

\begin{abstract}
The aim of this study was to identify types of adverse events, clinical manifestations and nursing care procedures adopted in response to adverse events to blood donation, and to verify the association between these procedures and the adverse events. This was an epidemiological, retrospective study conducted through analysis of 1369 records of treatment of adverse events to blood donation, during the period between January 2009 and December 2011. Descriptive statistics and contingency tables were used to analyze associations through the use of Cramér's V. A total of $92.6 \%$ of adverse events were classified as mild, and clinical manifestations were malaise, dizziness, pallor and sweating. The Trendelenburg position, vital signs monitoring, oral hydration and directions for care after blood donation were the main procedures adopted. A statistical significance was observed between the nursing procedures and the types of adverse events. The results point to the critical role of nursing in treating adverse events to blood donation.
\end{abstract} DESCRIPTORS: Blood donors. Nursing care. Blood safety.

\section{CONDUTAS DE ENFERMAGEM ADOTADAS DIANTE DOS EVENTOS ADVERSOS À DOAÇÃO DE SANGUE}

RESUMO: Esta investigação objetivou identificar os tipos de eventos adversos, as manifestações clínicas e condutas de enfermagem adotadas, e verificar a associação entre essas condutas e os eventos adversos ocorridos. Estudo epidemiológico, retrospectivo, realizado após a análise de 1369 fichas de atendimento de reações adversas à doação, no período compreendido entre janeiro de 2009 a dezembro de 2011. Utilizou-se estatística descritiva e tabelas de contingência para analisar a associação, empregando-se o coeficiente de Cramér. Foram 92,6\% eventos adversos classificados como leves e as principais manifestações clínicas foram mal-estar, tontura, palidez e sudorese. O posicionamento em Trendelemburg, aferição dos dados vitais, hidratação oral e as orientações quanto aos cuidados após a doação, foram as principais condutas adotadas. Observou-se significância estatística entre a maioria das condutas de enfermagem e os tipos de eventos adversos. Os resultados apontam para o decisivo papel da enfermagem perante a ocorrência dos eventos adversos à doação de sangue. DESCRITORES: Doadores de sangue. Cuidados de enfermagem. Segurança do sangue.

\section{CONDUCTAS DE ENFERMERÍA ADOPTADAS EN LOS EVENTOS ADVERSOS DE DONACIÓN DE SANGRE}

\begin{abstract}
RESUMEN: Esta investigación tuvo como objetivo identificar los tipos de eventos adversos, las manifestaciones clínicas y las conductas de enfermería adoptadas, así como verificar una asociación entre estas conductas y los eventos adversos. Estudio epidemiológico, retrospectivo realizado después del análisis de 1369 historias clínicas de las reacciones adversas a la donación, durante el período comprendido entre enero 2009 a diciembre 2011. Se utilizó estadística descriptiva y tablas de contingencia para analizar la asociación, así como el coeficiente de Cramer. Fueron clasificados como leves 92,6\% eventos adversos y las manifestaciones clínicas fueron malestar general, mareos, palidez y sudoración. La posición de Trendelenburg, la medición de los signos vitales, la hidratación oral y las directrices para el cuidado después de la donación fueron las principales conductas aprobadas. La significación estadística se observó entre la mayoría de los procedimientos de enfermería adoptados y los tipos de eventos adversos. Los resultados evidencian el papel fundamental de la enfermería antes de la ocurrencia de eventos adversos con la donación de sangre.
\end{abstract}

DESCRIPTORES: Donantes de sangre. Cuidados de la enfermería. Seguridad de la sangre. 


\section{INTRODUCTION}

Despite the advanced technology and care provided to protect donors, adverse events and undesirable effects from collection can occur during blood donation. These reactions are classified by hemotherapy services as mild, moderate and severe, depending on the clinical signs and symptoms presented by donors. ${ }^{1-3}$

In most hemotherapy services, blood collection from donors, post-donation directions and immediate care of adverse events are the responsibility of the nursing team, which consists of nurses, nursing assistants and technicians, under the supervision and guidance of a professional nurse.

The powers and duties of nursing in hemotherapy services are established and supported by the Brazilian Council of Nursing through resolution n. 306/2006. ${ }^{4}$

The recommendations provided to the nursing staff include the establishment of friendly and professional contact with donors, the provision of information about the procedure and possible complications from it, and the clarification of doubts focused on gaining donors and making them return for new donations. These actions contribute to donor satisfaction, as well as ensure quality and safety of the transfusion process, which starts with blood donation. The welcome can be regarded as the humanization of donor care, providing a sense of security and comfort, and thereby helping to minimize complications or adverse events that may arise from the donation procedure. $^{5-6}$

This study was proposed due to the scarcity of studies in nursing, and the need to know and standardize nursing procedures adopted for adverse events to blood donation. Moreover, it had the purpose of supporting the adoption of measures to minimize the impact of adverse events on donors and blood services.

The aim of this study was to identify the types of adverse events among whole blood donors and their clinical manifestations, to identify nursing care procedures adopted in response to these events, and to investigate the association between the procedures adopted and the types of events.

\section{METHODOLOGY}

This epidemiological, retrospective study was developed in a regional blood center that is part of Fundação Hemominas, located in the Triângulo Mineiro region, in the Brazilian state of Minas Gerais. This unit is specialized in hemotherapy and hematology, and on average, it serves 1500 candidates for blood donation, collects 1300 units of blood, treats 400 patients and performs 1900 transfusions per month.

Data were obtained from 1369 records of blood donations and treatment of adverse events to these, provided by the center collection room, registered and filled out by the nursing staff between January 2009 and December 2011.

In order to guide the data collection, a specific instrument was built from the records of blood donations and treatment of adverse events, standardized by the institution. This instrument covers the following aspects: donor identification data (gender, date of birth and marital status), types of events (mild, moderate or severe), clinical manifestations presented and/or reported by the donor, and nursing care provided and recorded on the patient records.

The types of adverse events to whole blood donation were classified according to Fundação Hemominas, ${ }^{2-3}$ based on clinical manifestations presented by the donor, including mild clinical complications (donor is anxious, complains of heat, presents fainting, sweating, pallor, dizziness, headache, nausea, malaise, increased or rapid and thready pulse, tachypnea leading to hyperventilation, sighing or yawning, absence of loss of consciousness, low blood pressure and bruises on the arm); moderate clinical complications (including mild symptoms plus nausea followed by vomiting, quick periods of unconsciousness, bradycardia, rapid shallow breathing, hyperventilation and continuous decrease of blood pressure - systolic BP $60 \mathrm{~mm} \mathrm{Hg}$ or less); and severe clinical complications (including mild to moderate symptoms plus seizures and tetany caused by severe hyperventilation).

Data were collected by the researcher after validation of the instrument (apparent content validation) by three physicians specialized on the subject, taking into account that it was built from the donation record recommended, adopted and used by Fundação Hemominas throughout the state of Minas Gerais.

After collection, the data were entered into a Microsoft Excel ${ }^{\circledR}$ spreadsheet using a Microsoft Windows XP® platform, validated by double entry, and subsequently exported to the 
software Statistical Package for Social Sciences (SPSS), version 17.0, for processing and statistical analysis.

To characterize the types of adverse events, clinical manifestations and nursing procedures adopted, descriptive statistics with simple and absolute frequency was used. Bivariate descriptive statistics and contingency tables were also used to analyze the association between types of adverse events that occurred and nursing care procedures adopted.

This association was measured using Cramér's coefficient of association (r), with the range presented by the Rugg table being used for the interpretation of the association between variables: $r<0.15$ indicator of negligible association; $r$ between 0.15 and 0.29 , low association; $r$ between 0.30 and 0.49 , significant association, and $r>0.50$, strong association. ${ }^{7}$ The results were considered significant at a level of $5 \%(\mathrm{p}<0.05 \%)$, and presented in the form of figures and tables.

The research project was approved by the research ethics committee of Fundação Hemominas under protocol n. 322. Because this was a retrospective study through the collection and analysis of data in the records of blood donations and treatment of adverse events to these, and none of the subjects were identified, the Free and Informed Consent was not necessary. Confidentiality of the identification of research subjects was ensured through the numbering of data collection instruments.

\section{RESULTS AND DISCUSSION}

In the retrospective period covered by this study (January 2009 to December 2011), 45,584 blood donations were made, with 1,369 adverse events reported, representing $3 \%$ of donations. Of the total number of adverse events, $51.1 \%$ occurred in male donors. The ages of donors ranged from 18 to 61 years, with a prevalence of 18 to $30(68.5 \%)$. $62.0 \%$ of donors were single and $28.2 \%$ married. The frequency of types of adverse events that occurred is presented in Figure 1.

There was a predominance of light or vasovagal reactions in 1,367 donors $(92.6 \%)$, which corroborates other studies conducted. However, the study had lower frequency rates of severe reactions, which diverges from other studies with similar research methodologies. ${ }^{8-12}$

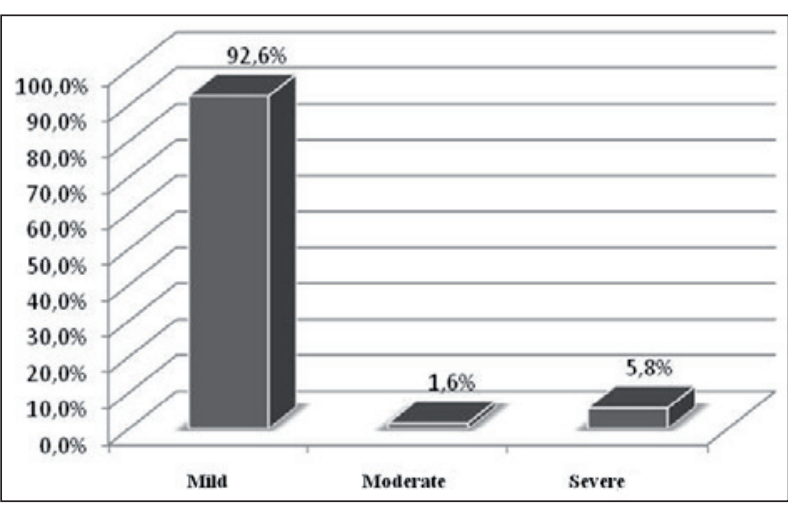

Figure 1 - Frequency of types of adverse events to blood donations reported by the nursing staff (2009-2011). Uberaba-MG, 2012

The nursing staff recorded the clinical manifestations of donors' adverse events to blood donations on treatment records, as shown in table 1, below.

Table 1 - Clinical manifestations of donors who experienced adverse events to blood donation ( $n=1,367), 2009-2011$. Uberaba-MG, 2012

\begin{tabular}{lcc}
\hline Clinical manifestations & n & \% \\
\hline Malaise & 701 & 51.3 \\
Dizziness/vertigo & 584 & 42.7 \\
Skin/facial pallor & 385 & 28.2 \\
Sweating & 380 & 27.8 \\
Nausea & 224 & 16.4 \\
Blurred vision & 205 & 15.0 \\
Complaints of heat or cold & 166 & 12.1 \\
Weakness/fatigue & 127 & 9.3 \\
Hypotension (BP<90 60 mmHg) & 121 & 8.9 \\
Collapse & 97 & 7.1 \\
Transient loss of consciousness & 78 & 5.7 \\
Muscle contractions & 69 & 5.0 \\
Paresthesia/tingling & 30 & 2.2 \\
Vomiting & 30 & 2.2 \\
Anxiety & 29 & 2.1 \\
Hematoma & 24 & 1.8 \\
Drowsiness & 20 & 1.5 \\
Headache & 12 & 0.9 \\
Convulsion & 3 & 0.2 \\
\hline
\end{tabular}

Among the 1,369 adverse events reported, $1,367(99.8 \%)$ had a complete and reliable record of the clinical manifestations presented by donors. 3,285 clinical manifestations were identified, with a mean of 2.4 clinical complications for each adverse event reported. The main clinical manifestations 
shown and/or reported by donors characterize the adverse events as mild, and reinforce their prevalence, supporting information presented in other literature. ${ }^{10,12}$

With regard to clinical manifestations, the frequency of dizziness and nausea were higher than in a prospective study undertaken in Greece, which also analyzed the symptoms and changes in vital signs of 107 donors who had adverse events during or after blood donation. ${ }^{13}$

Another study conducted in Pakistan had a higher prevalence of weakness and dizziness as characteristic signs and symptoms of adverse events. One study in Italy showed sweating and pallor, in addition to weakness and dizziness. These results corroborate the findings of this study, which also showed a prevalence of dizziness, pallor and sweating as the main symptoms. ${ }^{14-15}$

In this study, 24 (1.8\%) hematomas were recorded. This frequency is probably due to the fact that this type of adverse event was not considered in isolation, but rather associated with other clinical manifestations reported. The data obtained in this study is supported by a study conducted by the American Red Cross Blood Services in 2003, which showed a $1.7 \%$ incidence of hematomas. ${ }^{16}$

Other studies also demonstrated the low incidence of hematomas, which indicate local complications, with incidence less than $2 \%$. These studies draw attention to the need to quantify this type of adverse event. ${ }^{10,17}$

Regarding muscle contraction and transient loss of consciousness, the low frequency of these symptoms was noted in another study conducted at the Blood Center of Belo Horizonte, another unit of the Fundação Hemominas network. ${ }^{11}$

Regarding nursing care procedures adopted, of the 1,369 adverse events reported, 1,368 (99.9\%) records were complete, and appropriate nursing care was provided. 6,252 nursing care procedures were substantiated, averaging 4.6 procedures for each adverse event registered in the patients' records. Placing the donor in the Trendelenburg position, measurement of vital signs and oral rehydration were the main procedures adopted by the nursing staff. Table 2 shows the nursing procedures adopted.

With regard to nursing care, the procedures adopted corroborate other studies that describe a set of actions to be taken in the presence of adverse events. ${ }^{10,15,18}$
Table 2 - Nursing procedures adopted for treatment of adverse events to blood donations ( $\mathrm{n}=1368)$, 2009-2011. Uberaba-MG, 2012

\begin{tabular}{lrc}
\hline Nursing procedures & $\mathbf{n}$ & $\%$ \\
\hline Trendelenburg positioning & 1316 & 96.2 \\
Measurement of vital signs & 1309 & 95.7 \\
Oral hydration & 1128 & 82.5 \\
Post-donation directions & 808 & 59.1 \\
Directions for proper breathing & 662 & 48.4 \\
Interruption of collection & 355 & 26.0 \\
Request for medical evaluation & 345 & 25.2 \\
Intravenous hydration & 201 & 14.7 \\
Elevation of lower limbs & 23 & 1.7 \\
Administration of drugs & 20 & 1.5 \\
Family member contacted & 19 & 1.4 \\
Blood glucose monitoring & 14 & 1.0 \\
Other & 52 & 3.8 \\
\hline
\end{tabular}

In India, immediate care such as placing the donor in the Trendelenburg (antishock) position, elevation of lower limbs, discontinuing the procedure and providing liquids while still in the collection room were corrective measures taken in response to adverse events. ${ }^{10}$ Another study also revealed the adoption of antishock positioning and a low frequency of intravenous hydration and medication as therapeutic interventions. ${ }^{15}$

In addition to the Trendelenburg position, a review of reactions and injuries related to blood donation also showed directions for changing the breathing pattern as treatment. This study also cites on the need for monitoring blood pressure, pulse and mental state, especially with severe reactions. ${ }^{18}$

The measurement and recording of vital signs are immediate nursing care procedures, as they permit the initial evaluation of the donor and enable the planning of actions to be taken by the nursing staff, and in some cases, by the medical team as well.

Typically, donor first aid is performed by the nursing staff who, after evaluation and depending on the need, request intervention by the medical team. ${ }^{3}$ In one French study of 196 adverse events, two third of the cases required medical consultation and one third required hospitalization. ${ }^{19}$

The importance of the nursing work to monitor vital signs and constantly evaluate the donor in the treatment of clinical complications is clear. Multidisciplinary teamwork is crucial and necessary for rapid stabilization of the donor, as well as to ensure safe, quality care. 
The code of ethics for professional nurses emphasizes their participation in multi- and interdisciplinary work with responsibility, autonomy and freedom. ${ }^{20}$ This should guide the nursing actions led by a nurse who seeks the best scientific evidence for the procedures applied to the care practice, regardless of the work scenario. Nursing in hemotherapy is still a relatively new field, but it is growing by leaps and bounds, gaining space and recognition in academic and scientific communities, and impacting quality of care in this field.

Analysis of direction for proper breathing in one study states that the breathing pattern of the donor can be changed, and to minimize the effects caused by hyperventilation (increased concentration of carbon dioxide), donors can be encouraged to cough, hold their breath for five seconds, or even breathe into a paper bag. Chatting with donors and diverting their attention are also measures to reverse this reaction. ${ }^{18}$

Post-donation directions refer to explanations offered by the physician or by the nursing staff. Brazilian legislation states that the donor should be informed about possible adverse events to the donation, and provided with directions on how to cope with them. These directions must be provided prior to the donor's discharge. ${ }^{21}$

The incidence of hydration with intravenous fluids was higher than that found in the study in Italy, in which this procedure was used with 18 $(0.36 \%)$ donors with vasovagal reaction. In this study, the authors commented that the volume of blood collected in one donation (on average 450 $\mathrm{ml}$ ) represents only $10 \%$ of the total blood of an adult, and thus does not expose adult donors to risk of hypovolemic shock, and reduces the need for intravenous hydration. ${ }^{15}$

As for the association between types of adverse events and nursing care adopted and recorded, analysis of table 3 below shows that among the twelve (12) nursing care procedures associated with types of adverse events, there was a statistically significant association in nine of them. These include: intravenous hydration, request for medical evaluation, oral rehydration, Trendelenburg positioning and elevation of the lower limbs, drug administration, measurement of vital signs, blood glucose monitoring and contacting a family member.

Table 3 - Association between types of adverse events to blood donation and nursing care procedures adopted (2009-2011). Uberaba-MG, 2012

\begin{tabular}{|c|c|c|c|c|c|c|c|c|c|}
\hline \multirow{3}{*}{ Variables } & \multicolumn{9}{|c|}{ Types of adverse events } \\
\hline & \multicolumn{2}{|c|}{ Mild } & \multicolumn{2}{|c|}{ Moderate } & \multicolumn{2}{|c|}{ Severe } & \multirow[t]{2}{*}{$r(\mathrm{p})$} & \multicolumn{2}{|c|}{ Total $(n=1368)$} \\
\hline & $\mathbf{n}$ & $\%$ & $\mathbf{n}$ & $\%$ & $\mathbf{n}$ & $\%$ & & $\mathbf{n}$ & $\%$ \\
\hline \multicolumn{10}{|c|}{ Intravenous hydration } \\
\hline Yes & 150 & 11.8 & 10 & 45.5 & 41 & 51.3 & 0.28 & 201 & 14.7 \\
\hline No & 1116 & 88.2 & 12 & 54.5 & 39 & 48.8 & $(<0.001)$ & 1167 & 85.3 \\
\hline \multicolumn{10}{|c|}{ Medical evaluation } \\
\hline Yes & 258 & 20.4 & 18 & 81.8 & 69 & 86.3 & 0.39 & 345 & 25.2 \\
\hline No & 1008 & 79.6 & 4 & 18.2 & 11 & 13.8 & $(<0.001)$ & 1023 & 74.8 \\
\hline \multicolumn{10}{|c|}{ Procedure interruption } \\
\hline Yes & 327 & 25.8 & 4 & 18.2 & 24 & 30.0 & 0.03 & 355 & 26.0 \\
\hline No & 939 & 74.2 & 18 & 81.8 & 56 & 70.0 & $(0.501)$ & 1013 & 74.0 \\
\hline \multicolumn{10}{|c|}{ Offer oral hydration } \\
\hline Yes & 1059 & 83.6 & 14 & 63.6 & 55 & 68.8 & 0.11 & 1128 & 82.5 \\
\hline No & 207 & 16.4 & 8 & 36.4 & 25 & 31.2 & $(<0.001)$ & 240 & 17.5 \\
\hline \multicolumn{10}{|c|}{ Trendelenburg position } \\
\hline Yes & 1231 & 97.2 & 19 & 86.4 & 66 & 82.5 & 0.19 & 1316 & 96.2 \\
\hline No & 35 & 2.8 & 3 & 13.6 & 14 & 17.5 & $(<0.001)$ & 52 & 3.8 \\
\hline \multicolumn{10}{|c|}{ Elevation of lower limbs } \\
\hline Yes & 12 & 0.9 & 1 & 4.5 & 10 & 12.5 & 0.21 & 23 & 1.7 \\
\hline No & 1254 & 99.1 & 21 & 95.5 & 70 & 87.5 & $(<0.001)$ & 1345 & 98.3 \\
\hline \multicolumn{10}{|c|}{ Administration of drugs } \\
\hline Yes & 12 & 0.9 & 2 & 18.2 & 4 & 5.0 & 0.19 & 20 & 1.5 \\
\hline No & 1254 & 99.1 & 18 & 81.8 & 76 & 95.0 & $(<0.001)$ & 1348 & 98.5 \\
\hline
\end{tabular}




\begin{tabular}{|c|c|c|c|c|c|c|c|c|c|}
\hline \multicolumn{10}{|c|}{ Measurement of vital signs } \\
\hline Yes & 218 & 96.2 & 20 & 90.9 & 71 & 88.8 & 0.09 & 1309 & 95.7 \\
\hline No & 48 & 3.8 & 2 & 9.1 & 9 & 11.2 & $(0.003)$ & 59 & 4.3 \\
\hline \multicolumn{10}{|c|}{ Blood glucose monitoring } \\
\hline Yes & 9 & 0.7 & - & - & 5 & 6.3 & 0.13 & 14 & 1.0 \\
\hline No & 1257 & 99.3 & 22 & 100.0 & 75 & 93.7 & $(<0.001)$ & 1354 & 99.0 \\
\hline \multicolumn{10}{|c|}{ Post-donation directions } \\
\hline Yes & 754 & 59.6 & 12 & 54.5 & 42 & 52.5 & 0.03 & 808 & 59.1 \\
\hline No & 512 & 40.4 & 10 & 45.5 & 38 & 47.5 & $(0.419)$ & 560 & 40.9 \\
\hline \multicolumn{10}{|c|}{ Directions on proper breathing } \\
\hline Yes & 620 & 49.0 & 9 & 40.9 & 33 & 41.2 & 0.04 & 662 & 48.4 \\
\hline No & 646 & 51.0 & 13 & 59.1 & 47 & 58.8 & $(0.317)$ & 706 & 51.6 \\
\hline \multicolumn{10}{|c|}{ Contact family member } \\
\hline Yes & 8 & 0.6 & 1 & 4.5 & 10 & 12.5 & 0.24 & 19 & 1.4 \\
\hline No & 1258 & 99.4 & 21 & 95.5 & 70 & 87.5 & $(<0.001)$ & 1349 & 98.6 \\
\hline
\end{tabular}

Although the degree of association between intravenous hydration and drug administration and each type of adverse event was considered low, it was observed that as severity of clinical complications increased, these procedures were adopted more frequently.

Among the recurring nursing procedures, requesting medical evaluation and/or intervention had a stronger degree of association $(\mathrm{r}=0.39)$, and can be taken as an indicator of significant association. Medical evaluation was requested by the nursing staff in 69 severe events $(86.3 \%)$.

It is essential to emphasize the commitment of the medical and nursing teams in the treatment of adverse events, especially severe clinical complications. Teamwork enables the construction of a care project common to the different members of the team, providing for safe, effective and systematic care.

In regard to the need for drug administration, it was observed that this procedure has been used more frequently in reactions classified as moderate. This finding is probably due to the fact that with this type of event, donors may have nausea and vomiting, which often requires medication for their stabilization.

Between lower limb elevation and types of adverse events, there was a small degree of association $(r=0.21)$, with significant increase in its incidence as the severity of clinical complications increases.

The association between the measurement of vital signs and adverse events was statistically significant ( $p=0.003)$; however, when considering the Rugg table, this association is negligible $(r=0.09)$, despite the high incidence of this procedure in response to mild events. This indicator was also observed in association with blood glucose monitoring $(\mathrm{r}=0.13)$; however, this nursing procedure was adopted with greater frequency in severe events $(6.3 \%)$.

The need to contact a family member of the donor, usually for transportation, proved to be a low indicator of association with types of adverse events $(\mathrm{r}=0.24)$. In addition, as the severity of clinical manifestations increases, there is an increase in the incidence of this procedure, adopted in 10 $(12.5 \%)$ cases of treatment of severe reactions.

The analysis of the association of nursing care procedures and types of adverse events enables the evaluation of results and quality of care provided, with the possible development of indicators for nursing care, which impacts the development and improvement of management processes. ${ }^{22}$

In view of clinical complications, nurses and the nursing staff are responsible for providing first aid. Nurses in hemotherapy should know and master the different types of adverse events and their clinical manifestations, in order to plan and systematize the nursing care, standardize procedures and routines, as well as promote qualification of the service. This certainly ensures the provision of scientific and grounded nursing care. ${ }^{23}$

\section{CONCLUSION}

In this study there was a predominance of mild adverse events to blood donation (92.6\%) in donors who were male $(51.1 \%)$, single $(62.0 \%)$ and aged between 18 and 30 years (68.5\%). Malaise, dizziness, pallor and sweating were the most 
frequent clinical manifestations on the patients records analyzed. The primary nursing care procedures adopted were: Trendelenburg positioning, measurement of vital signs, oral rehydration, and providing directions for post-donation and proper breathing technique.

There was a statistically significant association $(p<0.05)$ between the types of adverse events and the following nursing procedures: intravenous hydration, request for medical evaluation, oral hydration, Trendelenburg positioning, elevation of lower limbs, drug administration, measurement of vital signs, blood glucose monitoring and contacting a family member.

Nurses working in hemotherapy services must be familiar with this potential population; encourage their team to provide systematic care; encourage and promote continuing education of their staff; as well as disseminate public policies to encourage voluntary blood donation, becoming a benchmark in the development of strategies to sensitize society to this need.

The results of this study are expected to support the development of prospective studies with this population, in order to investigate risk factors and design new strategies for reducing adverse events to blood donation.

\section{REFERENCES}

1. Lopes MI. A doação de sangue. In: Textos de apoio em hemoterapia, organização pela Escola Politécnica da Saúde Joaquim Venâncio. Rio de Janeiro (RJ): Fiocruz; 2000. V. 1, p. 49-68.

2. Fundação Hemominas. Manual da assistência de enfermagem. Belo Horizonte (MG): Fundação Hemominas; 2012.

3. Fundação Hemominas. Manual de normas e procedimentos de atendimento ao doador. Belo Horizonte (MG): Fundação Hemominas; 2012.

4. Conselho Federal de Enfermagem. Resolução n. 306, de 25 de abril de 2006 [online]. Normatiza a atuação do enfermeiro em hemoterapia. Rio de Janeiro (RJ): COFEN; 2012 [acesso 2012 Ago 10]. Disponível em: http:/ / novo.portalcofen.gov.br/ resoluo-cofen-3062006_4341.html

5. Borges TS, Vidigal DC, Chaves JM. Cadernos Hemominas: assistência de enfermagem na coleta de sangue do doador e na hemotransfusão. Belo Horizonte (MG): Fundação Hemominas; 2004.

6. Rodrigues RSM, Reibnitz KS. Estratégias de captação de doadores de sangue: uma revisão integrativa da literatura. Texto Contexto Enferm. 2011 Jun; 20(2):384-91.
7. Rodrigues PC. Bioestatística. Niterói (RJ): EdUFF; 2002.

8. Ogata H, Iinuma N, Nagashima K, Akabane T. Vasovagal reactions in blood donors. Transfusion. 1980 Nov-Dec; 20(6):679-83.

9. Múnera MI, Ramírez BS, Zapata CM, Marín DS. Reacciones adversas inmediatas a la donácion: frecuencia y caracterización, banco de sangre de la clínica cardiovascular Santa María, Medellín, 1999. Biomédica. 2001; 21(3):224-7.

10. Pathak C, Pujani M, Pahuja S, Jain M. Adverse reactions in whole blood donors: an Indian scenario. Blood Transfus. 2011 Jan; 9(1):46-9.

11. Chaves JM, Moura OA. Avaliação dos Registros das Intercorrências e Reações adversas no processo de doação de sangue no Hemocentro de Belo Horizonte, no período de 20 de novembro a 19 de dezembro de 2004 [trabalho de conclusão de curso]. Belo Horizonte (MG): Escola de Saúde Pública; 2005.

12. Gonçalez TT, Sabino EC, Schlumpf KS, Wright DJ, Leao S, Sampaio D, et al. Vasovagal reactions in whole blood donors at three REDS-II blood centers in Brazil. Transfusion. 2012 Mai; 52(5):1070-8.

13. Zervou EK, Ziciadis K, Karabini F, Xanthi E, Chrisostomou E, Tzolou A. Vasovagal reactions in blood donors during or immediately after blood donation. Transfus Medicine. 2005 Out; 15(5):389-94.

14. Rohra DK, Juriasinghani V, Rai K, Azam SI. Prevalence of immediate vasovagal reaction in blood donors visiting two blood banks of Karachi. Transfusion Med. 2010 Jun; 20(3):129-33.

15. Crocco A, D'elia D. Adverse reactions during voluntary donation of blood and/or blood components. A statistical-epidemiological study. Blood Transfusion. 2007 Jul; 5(3):143-52.

16. Newman BH, Pichette S, Pichette D, Dzaka E. Adverse effects in blood donors after whole-blood donation: a study of 1000 blood donors interviewed 3 weeks after whole-blood donation. Transfusion. 2003 Mai; 43(5):598-603.

17. Newman BH, Newman DT, Ahmad R, Roth AJ. The effects of whole-blood donor adverse events on blood donor return rates. Transfusion. 2006 Ago; 46(8):1374-9.

18. Newman BH. Donor reactions and injuries from whole blood donation. Transfus Med Rev. 1997 Jan; 11(1):64-75.

19. Rebibo D, Danic B. Haemovigilance donors: methods and results. Transfus Clin Biol. 2007 Mai; 14(1):142-6.

20. Conselho Federal de Enfermagem. Resolução COFEN n. 311/2007 [online]. Aprova a reformulação do código de ética dos profissionais de enfermagem. Rio de Janeiro (RJ): COFEN; 2012 [acesso 2012 Set 12]. Disponível em: http://www.portalcofen.gov. br/sitenovo/node/4158 
21. Ministério da Saúde (BR) [online]. Portaria n. 1353, de 13 de junho de 2011. Aprova o Regulamento Técnico de Procedimentos Hemoterápicos. D.O.U, Brasília (DF), 14 jun 2011 [acesso em 14 ago. 2012]. Disponível em: http://bvsms.saude.gov.br/bvs/ saudelegis/gm/2011/prt1353_13_06_2011.html

22. Almeida RGS, Mazzo A, Mendes IAC, Trevisan MA, Godoy S. Caracterização do atendimento de uma unidade de hemoterapia. Rev Bras Enferm. [online]. 2011 [acesso 12 Set 2012]; 64(6):1082-6. Disponível em: http://www.scielo.br/pdf/reben/ v64n6/v64n6a14.pdf

23. Guerrero GP, Beccaria LM, Trevisan MA. Procedimento operacional padrão: utilização na assistência de enfermagem em serviços hospitalares. Rev Latino-Am Enferm. [online]. 2008 [acesso 12 Set 2012]; 16(6):966-72 Disponível em: http://www. scielo.br/pdf/rlae/v16n6/pt_05.pdf 